\title{
FOTOS DE FAMILIA ARCHIVO DE LA MEMORIA TRANS
}

\author{
FAMILY PHOTOGRAPHS \\ ARCHIVE OF THE TRANS MEMORY
}

Cecilia Estalles Alcón | archivotrans@gmail.com

Archivo de la Memoria Trans. Buenos Aires. Argentina

Recibido: 10/3/2018 | Aceptado: 17/6/2018

\section{RESUMEN}

En las imágenes que integran el Archivo de la Memoria Trans desbordan sonrisas vestidas con los mejores hilos capturadas, aparentemente, antes de una noche de fiesta en alguna ciudad. La alegría por la vida, la reunión, los abrazos, vuelven evidente la hermandad en este archivo de mujeres trans de los años ochenta y noventa en la Argentina. Estas mismas fotos trabajan el contrapunto de muchas vidas signadas por la persecución, la muerte, la segregación y la violencia. Como un gran álbum familiar, el archivo motiva encuentros, historias y recuerdos de quienes sobreviven y de las que ya no están.

\section{PALABRAS CLAVE}

Archivo de la Memoria Trans; identidad; historia; fotografía

\section{ABSTRACT}

The images that integrate the Archivo de la Memoria Trans [Archive of the Trans Memory] show smiles wearing their best clothes, captured before a night out in town. The joy for life, the meeting and the hugs make the family bond evident in this archive of women in the 80s and 90s in Argentina. These photos picture the counterpoint of many lives marked by persecution, death, segregation and violence. Like a great family album, the archive motivates encounters, stories and memories of those who survive and those who are no longer present.

\section{KEYWORDS}

Archivo de la Memoria Trans; identity; history; photography 
Por el año 2014 me enteré de la existencia de un grupo de Facebook llamado Archivo de la Memoria Trans. Estaba realizando un trabajo sobre la muerte de Gina Vivanco, una travesti asesinada por la policía en 1991. Cuando conocí a María Belén Correa, la creadora de este grupo, le propuse trabajar con ella y, muy generosamente, aceptó.

María Belén y Claudia Pía Baudracco, una reconocida activista trans, ya fallecida, habían imaginado tener un espacio donde recordar a sus compañeras. Después de la muerte de Pía Belén, creó un grupo cerrado en Facebook llamado Archivo de la Memoria Trans, en el que reunió a sus compañeras con un fin admirable. En el encabezado del grupo, que hoy contiene 1300 personas trans, Belén escribió: «Espacio para la recolección y protección de la memoria trans en fotos, recortes, vídeos, revistas, películas y entrevistas, pero sobre todo en historias contadas por las sobrevivientes» (Archivo de la Memoria Trans, 2018). Este es el recorte y la particularidad de este archivo, las historias son en primera persona. Las fotografías, que van desde los 80 hasta los 2000, fueron tomadas por ellas mismas. Y estas sobrevivientes están por muchos lados del mundo, algunas en Buenos Aires, otras en Santiago del Estero, en Roma, en Rosario, en Jujuy, en Salta o en París.

Belén es una de ellas, actualmente vive en Alemania, se fue, como la mayoría, exiliada, cuando ya no quedaba otra, te ibos o te ibon. La policía tenía vía libre para lo que quisiera y dos edictos policiales, vigentes hasta el año 1998 en Capital Federal, apuntaban al exterminio de lo diferente. Se podía ir presa hasta noventa días, de acuerdo al Artículo 2 inciso f, "por exhibirse vestidos o disfrazados con ropas del sexo contrario» 0 "por incitar u ofrecerse públicamente al acto carnal, sin distinción de sexos» (Policía Federal, 1959, s/p).

Las imágenes reflejan el adentro, pocas veces hay un exterior; en esos tiempos había que cuidarse. Pero se ve un gran momento en el que todo estaba permitido: los desfiles en los carnavales de los ochenta y los noventa. Allí ellas eran ellas, estaban muy cerca de lo que soñaban y de lo que querían para sus vidas, y la sociedad era más amable, era una festividad colectiva, una explosión de color, de baile, de cierta armonía.

El grupo de Facebook, que es la cocina del Archivo, funciona de forma cerrada. Las piezas son fotos, anécdotas, chistes, van dialogando entre ellas hasta llegar a un mapa aproximado de la amiga que no está. Arman un nuevo retrato, colectivo, y descubren cosas, detalles que se habían olvidado de sus amigas que perdieron en el camino, cosas que no se ven en las fotos, que están en la órbita del recuerdo, del mirar con nostalgia y con firmeza para adentro y recordar, entre todas, el olor a ese perfume que la caracterizaba, ese timbre de voz que era solo de ella, los gestos, los silencios, los gustos, quién le puso el nombre nuevo, las sutilezas que se pierden sin en el ejercicio de la memoria colectiva. Ahora ellas no son 
las mismas. Las que la cuentan tienen cuarenta años o más, no son las mismas, estamos en otra época, ahora podemos llamarlas sobrevivientes.

Las imágenes se sienten vivas a pesar de tanta muerte, tal vez sea porque están saliendo a la luz, están naciendo. Entre todas, construyen un relato, el relato más próximo y verdadero que puede existir sobre la comunidad, una nueva fotografía de un escenario para muchos y para muchas desconocido, incluso hoy, o mal conocido; históricamente exhibido a las masas por los medios de comunicación hegemónicos de un forma ridiculizada, grotesca, demonizada, en fin, transfóbica, en consonancia con las políticas estatales operantes de la época.

Como fotógrafa me resulta casi imposible no comparar estas imágenes con las de fotógrafos y fotógrafas de esta época de la escuela de Nan Goldin o con ella misma; es que formalmente son hermanas, la fórmula del flosh directo, cámara pocket, la vida cotidiana, las minorías. Y si bien hay algo que las acerca al mundo de la fotografía autoral, hay también algo que las aleja y es su intención. Estas imágenes nunca quisieron ser algo más. No pretendían estar en una sala de exhibición, ganar un premio o ser un fotolibro. Estas fotografías querían y se conformaban con ser el fotorecuerdo, la anécdota, el álbum familiar que, generalmente, no existió en la biblioteca de la infancia y de la adolescencia de las chicas. Estas imágenes empiezan ahora a ser imprescindibles, no ya desde su contenido visual, que es muy potente, sino desde el mensaje; están siendo porque la sociedad las prohibió, las anuló, las invisibilizó, las ocultó, y ya no estamos hablando solo de fotografías.

Siempre se me viene a la cabeza algo que dice María Belén Correa (en Belucci, 2015) en las entrevistas: «Nos volvimos activistas sin darnos cuenta» (S/P). Creo que hay algo de eso en las fotos, están siendo sin siquiera haberlo planeado y ya no hay retorno. Es que cuando la militancia te atraviesa en el cuerpo, porque ya el mismo cuerpo es un acto político, no hay forma de pensarse sin ella y llega, quizá, sin la conciencia de ser, y con el tiempo es, somos en constante transición. Luego de trabajar dos años en el proyecto junto con María Belén, a fines de 2016 comenzamos a sumar fotógrafas y compañeras sobrevivientes trans al equipo y abrimos la experiencia al trabajo colectivo. Hoy somos diez personas las que componemos el equipo del Archivo de la Memoria Trans. Nuestra metodología es simple: recibimos a quienes quieran donar o compartir imágenes, hacemos una entrevista y comenzamos con el proceso de preservación digital. Una vez digitalizadas las imágenes, son catalogadas y devueltas a sus dueñas o quedan en custodia del Archivo en caso de donación. Estamos organizadas en áreas que toman decisiones independientes, pero siempre consensuadas en equipo.

Este año recibimos el Premio Ibermemoria, que nos va a permitir, además de equiparnos, acondicionar y ordenar el material. Por medio de una plataforma web, el archivo estará abierto al público. 
El Archivo es un lugar de investigación, aprendizaje, contención y catarsis; es la memoria individual que se comparte, se abre y se transforma en memoria colectiva viva. La expulsión familiar a temprana edad, la calle, el departamento privado, la prostitución, sobrevivir, estar en pie, el humor, las peleas, las complicidad, los policías y gobiernos, la lucha colectiva, el bagayo, las muertes, la cárcel; son fotografías y paisajes frecuentes a los que recurrimos y nos detenemos para no pasar por alto nuestra propia historia. Una historia compartida con rasgos comunes que hablan de nuestra identidad Latinoamericana [Figura 1].

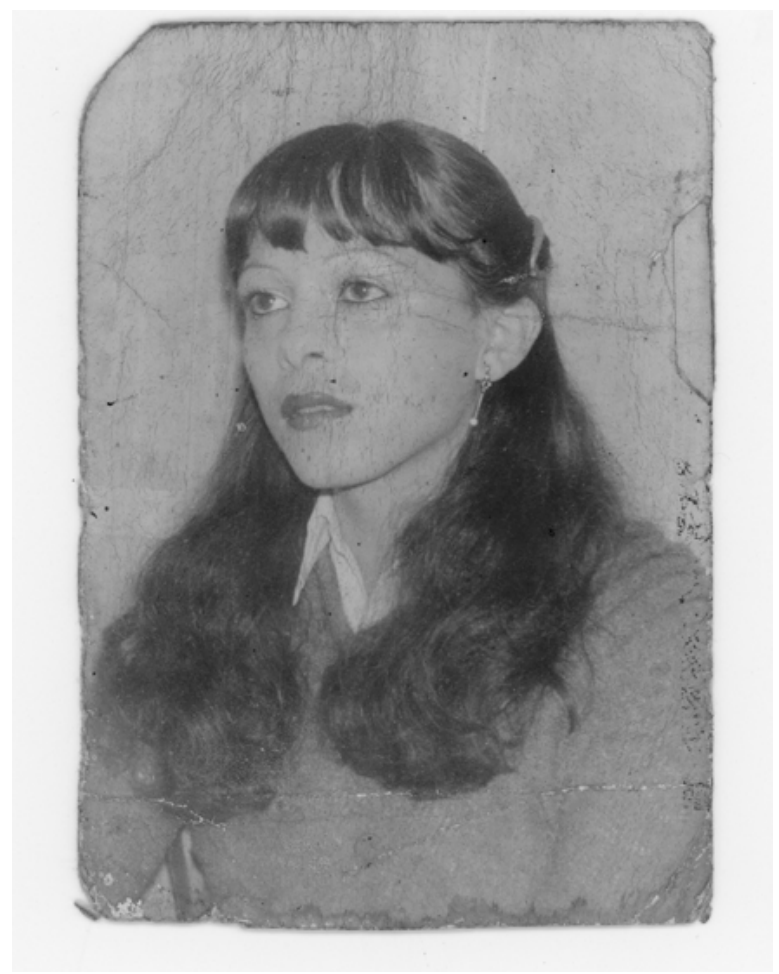

Figura 1. Julieta Gonzáles «La Trachi». Archivo de la Memoria Trans 


\section{REFERENCIAS}

Archivo de la Memoria Trans. (2018). Descripción. Recuperado de https:// www.facebook.com/pg/Archivo-De-La-Memoria-Trans665994070190218/ about/?ref=page_internal

Belucci, M. (2015). Entrevista a María Belén Correa. Revisto Furias, 26. Recuperado de http://contrahegemoniaweb.com.ar/nos-volvimos-activistas-sin-darnos-cuenta/

Policía Federal. (1959). Reglamento de procedimientos contravencionales y edictos policiales. Buenos Aires, Argentina: Ministerio del Interior. 